\title{
Examining the sustainability of urban furnitures and their potential to be a landmark in the scale of Rize city center
}

\author{
Kentiçi kent donatıların sürdürülebilirliği ve landmark olabilme potansiyelinin Rize kent merkezi ölçeğinde araştırılması
}

Deryanur DINÇER ${ }^{1}$ Banu BEKCi ${ }^{1}$. Fatih BEKIRYAZICl ${ }^{1}$

${ }^{1}$ Deparment of Landscape Architecture, Faculty of Fine Arts, Design and Architecture, Recep Tayyip Erdoğan University, Rize, Turkey

Eser Bilgisi / Article Info

Araştırma makalesi / Research article

DOI: 10.17474/artvinofd.627498

Sorumlu yazar / Corresponding author

Fatih BEKIRYAZICI

e-mail: fatihbekiryazici@hotmail.com

Geliş tarihi / Received

01.10.2019

Düzeltme tarihi / Received in revised form

09.04.2020

Kabul Tarihi / Accepted

12.04.2020

Elektronik erişim / Online available

11.06.2020

\section{Keywords:}

Urban furniture

Urban identity

Urban aesthetics

Landmark

Rize

Anahtar Kelimeler:

Kent donatısı

Kent kimliği

Kent estetiği

Landmark

Rize

\section{INTRODUCTION}

People got the feeling of space on the place where it exists and made it a special place for themselves, reducing it to its own units under the need to protect himself from the negative effects of nature (Güremen 2011).

Space is limited and has a purpose and many physical connections, but becomes a place when it is composed of cultural and regional content. While locations are evaluated in different categories based on their physical characteristics, each design is unique with its environmental characteristics and impact. Design characters include both concrete properties such as material, form, texture and color, as well as humancreated cultural compositions over time (Tranck 1986). Urban spaces symbolizing open spaces are directly related to the architectural space, which is essentially the embodiment of the existential space. Although the continuity between the urban space and the architectural space had different meanings in the past, the architectural space and the independent building which have undergone structural and perceptual isolation along with modernism have adopted the structural character of the islands (Öksüz 2004). The quality of urban green spaces also depends on the perceptions and preferences of the people and their environmental needs. In this context, the physical properties of urban green spaces and the activities they offer play a major role in the 
impact of users on their mental-physical-social well-being (Yilmaz et al. 2017). The environment created by both buildings and structures and light green spaces should not only have functionality that meets human biological needs, but also aesthetic qualities that meet psychological and intellectual needs (Erdoğan 2006).

The equipment elements are the objects that facilitate the individual and social life of people within the urban fabric, provide communication between the individuals, give the space a certain meaning in terms of functional and aesthetic, and have different qualities and quantities, define and complete the space (Düzenli et al. 2018). For this reason, equipment elements are of great importance not only for functional purposes, but also for the exhilarating effects of urban landscape. These structural elements, which mostly direct and guide pedestrians, are indispensable building blocks of multi-purpose planning. It should not be forgotten that these elements have to address each individual living in the city. This situation gives priority to the habits and lifestyles of people of all ages and emphasizes the rules of living together in the city (Can and Karakaş 2005). Thus, the collective life can be maintained with every design element used (Güney et al. 1996).

Each of the urban equipment elements that make the city livable and perceptible has a different meaning and importance in terms of users and the city. The importance of these elements for the users is that the visual and physical relationship they have established with the city is through the means of urban equipment. In terms of the city, these elements have the characteristics that define, determine and customize the environment in which they are located. The elements that are considered in a certain order, integrated with their environment and become an element of the city contribute to the formation of a city with the language union they have established with each other. Therefore, approaches should be developed to establish a continuous relationship with the urban spaces where urban equipment elements are located (Güremen 2011).

\section{Urban Equipment and Their Relations with Urban Identity}

Lynch briefly describes urban identity with "singularity" (Lynch 1973). The urban identity includes all the physical, social, cultural, historical and economic characteristics that differentiate one city from other cities (Diker and Çolpan Erkan 2017). The cities, which provide the coexistence of people in various cultures and social structures, have different social characteristics. At this point, the city identity is one of the important tools that reveal the different qualities of cities. The relationships and the functional needs of the people living in the city affect the urban identity (Ujang 2009, Tekeli 1991).

While the image of a city is revived in the mind of a city, its activities in the city, the social structure in the city and the meaning of the city for the people are taken into account, but the identity of the city includes the image of the city. The image of the city is a concept that consists of the elements remembered in the city and completes the identity of the city.

The sense of belonging to a city is considered to be about the fact that sign elements have a value representing the local identity (Moon et al. 2010) and are recognized by everyone (Appleyard 1969, Beattie 1990). At this point, landmarks have an important role in defining the settlement, forming a reference and enabling people to remember that settlement later (Madran 2001). Landmarks, which reflect the physical characteristic in the best way, are unique elements that are easily remembered in the context.

According to Lynch who emphasizes urban environment effects, 'effective tissue' elements generally have a great importance for individuals to perceive and understand the urban space in which they live. These items are classified as urban areas, boundaries, landmark, nodes and paths. These structural components in urban space are important elements that enable the city's residents and newcomers to understand the city (Lynch 1981).

Landscape elements which facilitate social life, receive users' appreciation, are located in streets, roads, squares and common or private use areas for recreation, support 
and strengthen basic functions such as living, sheltering, protection, surrounding, transportation, consultation, lighting, communication, description, games and sports, which are the signs of comfort and environmental quality, are called "urban equipment" (Başal et al. 1997). The qualities and organizations of common urban spaces and urban facilities play a crucial role in the formation of urban identity and the character and life of urban areas. (Güremen 2011).

Urban furnitures (floor coverings, sidewalks, staircases, ramps, curbs, seating elements, shading elements, flower beds, bus stops, pools, fountains, plastic elements, sculptures, telephone booths, buffet / kiosks, shaping public spaces, elements such as lighting elements, deterrent and limiters, trash cans, signs and baffle plates, information communication boards, landscape, etc.) are highly effective on the environmental image with their physical and visual characteristics (Güremen 2011).

The simplicity of urban furnitures in the design process shows that every element designed within the humanvehicle-environment system is a part of this system. Therefore, future requirements should be taken into account when designing equipment elements and the possibilities should be considered. The urban equipment elements, which customize the urban spaces, provide functional characteristics, respond to the needs of the users and make them useable, should be designed in a free and rhythmic order, and should establish a bond with each other and the built environment. In addition, the equipment elements must be of a nature that defines the space and the contribution of materials and color choices to the whole should be considered in their designs. In this study, the physical and environmental characteristics and sustainability of urban furnitures, sculptures and equipment used in the city center of Rize were evaluated and their gains to the city were determined by questioning their potential to become a landmark.

\section{MATERIALS AND METHODS}

\section{Description of the study area}

Rize is a coastal city located in the Eastern Black Sea region and has a characteristic natural beauty. The study areas selected by taking these beauties into consideration were determined within the boundaries of Rize City Center. Sculptures, fountains, urban furnitures and equipments subject to the study were divided into four groups. All of them was located in the places where people use more in daily life. Each unit entering into this grouping was evaluated with a minimum of 4 and maximum 6 parameters (Figure 1).

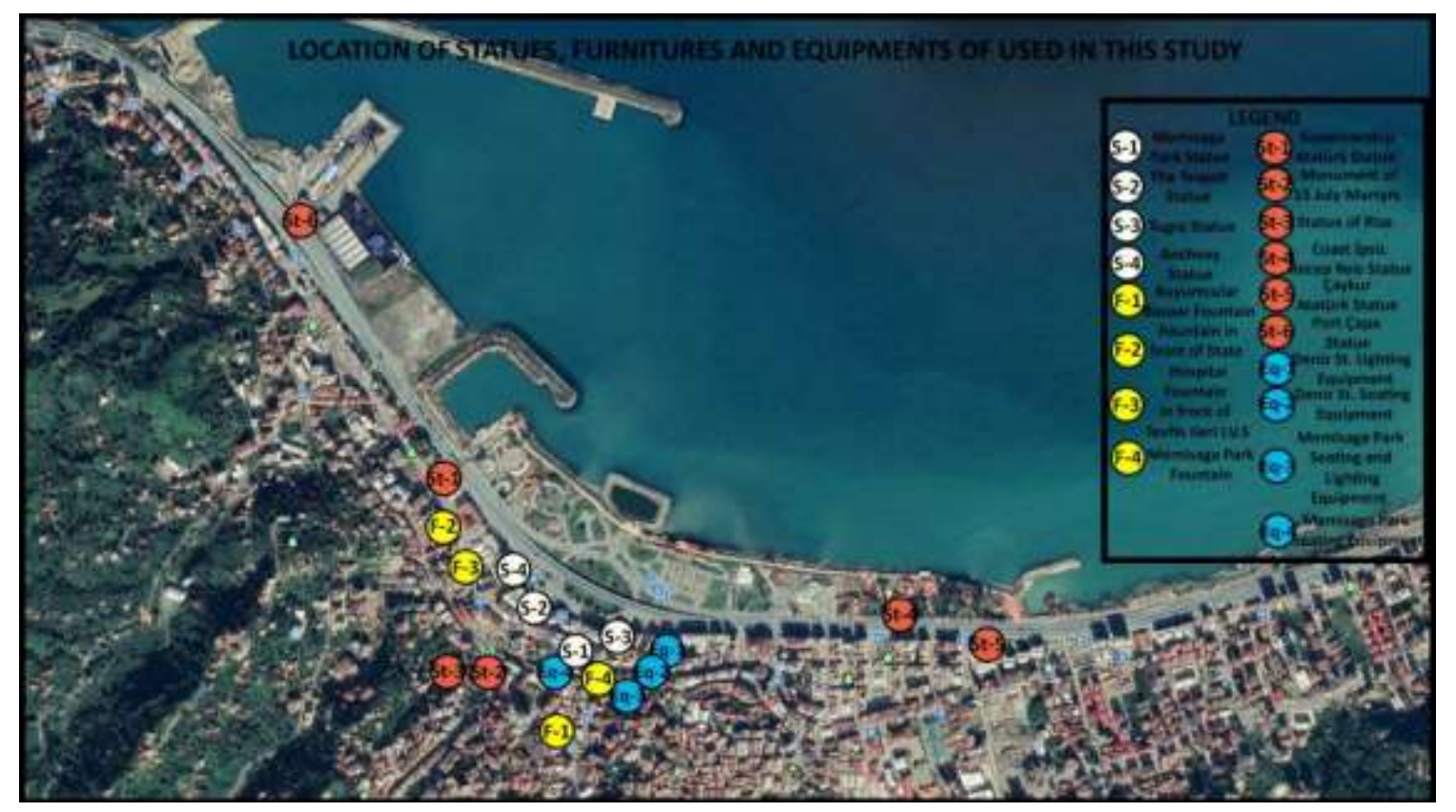

Figure 1. Map locations of objects used in the study 

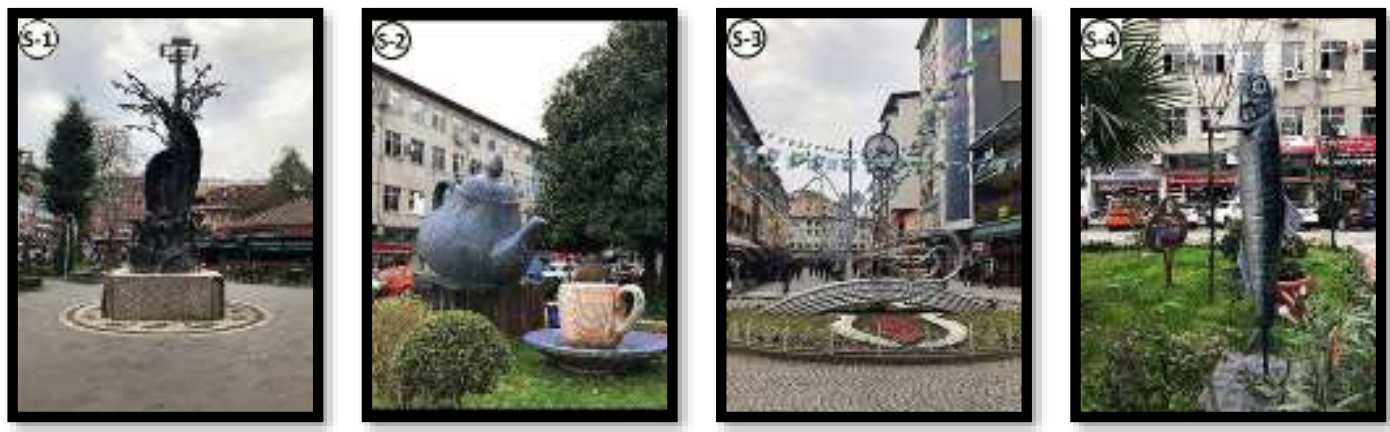

Figure 2. Statue group abbrevations, S-1: Memisaga Park Statue, S-2: The Teapot Statue, S-3: Tugra Statue, S-4: Anchovy Statue
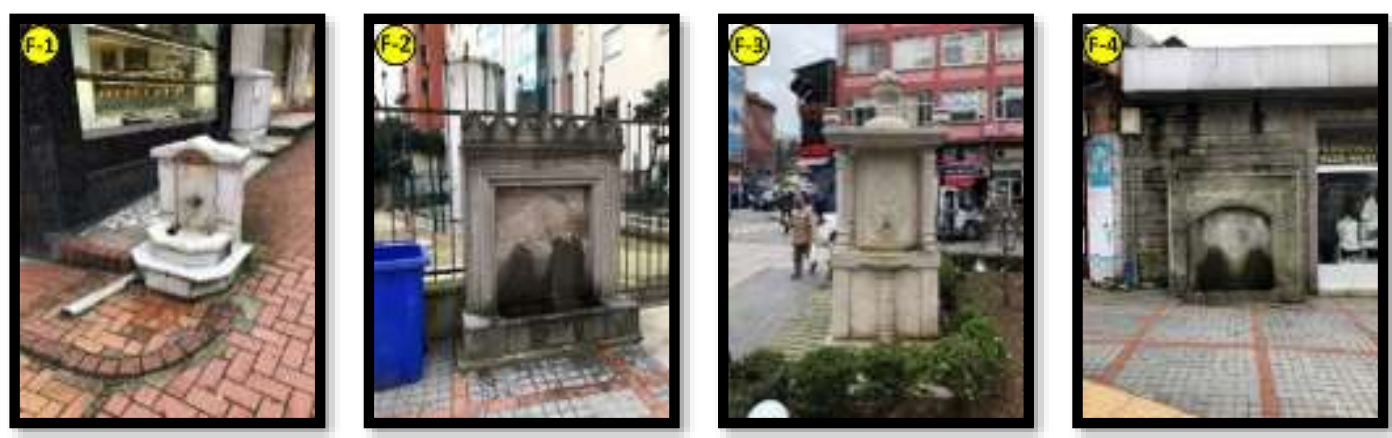

Figure 3. Fountain group abbrevations, F-1: Kuyumcular Bazaar Fountain, F-2: Fountain in front of State Hospital, F-3: Fountain in front of Tevfik lleri I.V.S, F-4: Memisaga Park Fountain
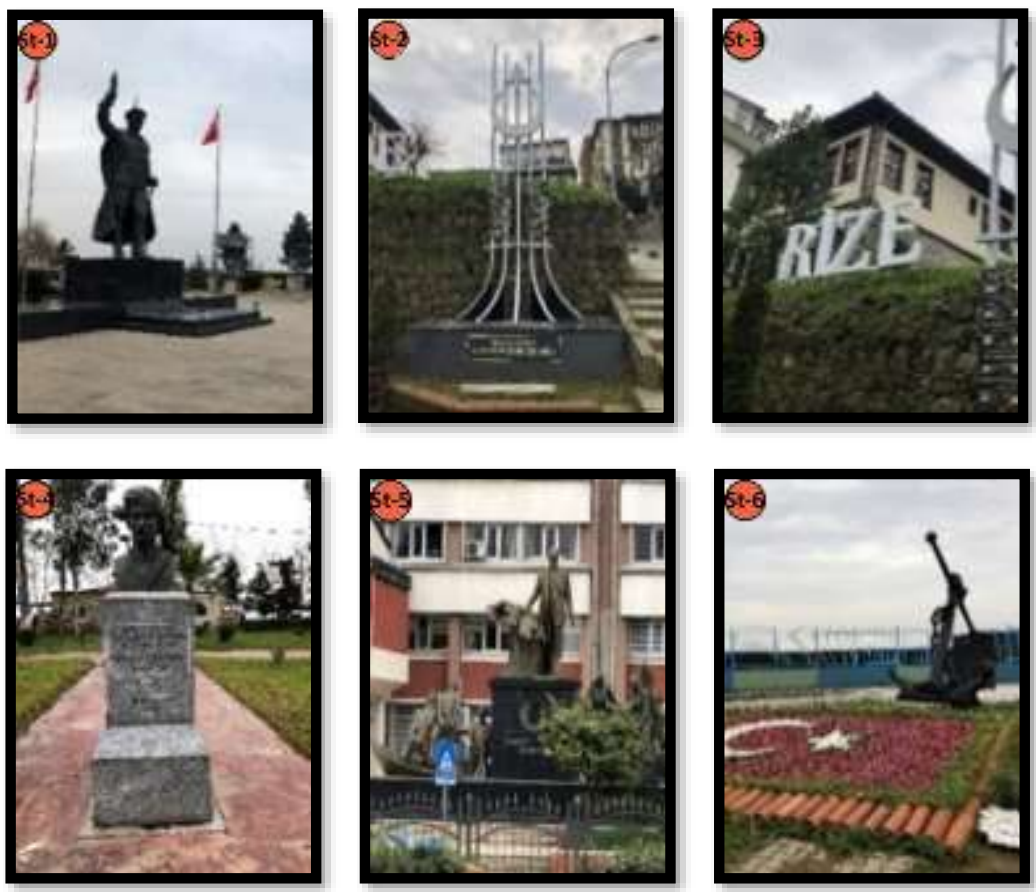

Figure 4. Landmark group abbrevations, St-1: Governorship Atatürk Statue, St-2: Monument of 15 July Martyrs, St-3: Statue of Rize, St-4: Coast Ipsiz Recep Reis Statue, St-5: Çaykur Atatürk Statue, St-6: Port Çapa Statue 

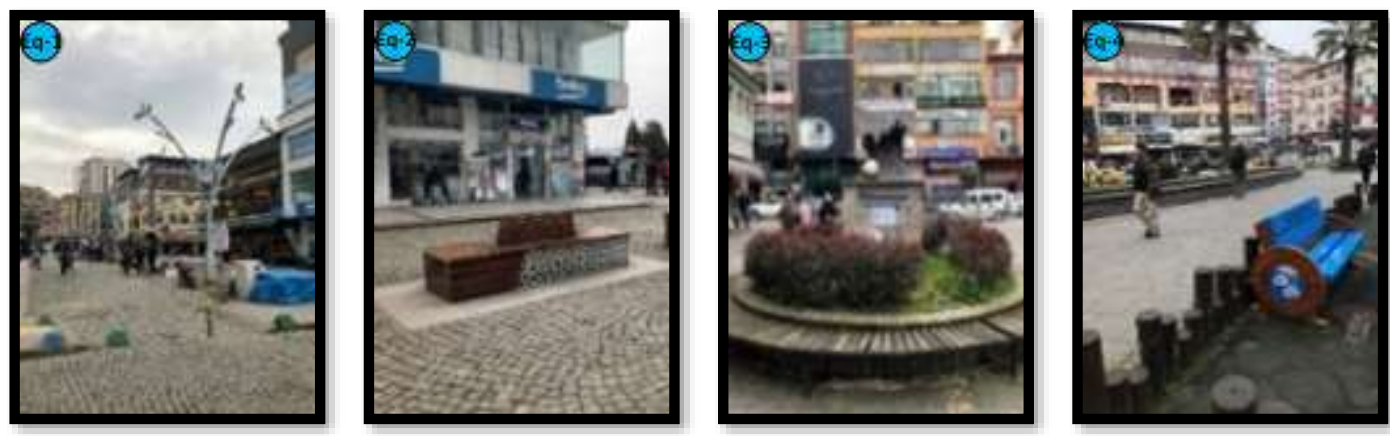

Figure 5. Equipment group abbrevations, Eq-1: Deniz St. Lighting Equipment, Eq-2: Deniz St. Seating Equipment, Eq-3: Memisaga Park Seating and LightingEquipment, Eq-4: Memisaga Park Seating Equipment

\section{Data Collection and Evaluation}

In the study, the characteristics of the selected objects, their dimensions, functions, their harmony with the environment and their environment, their material diversity and suitability, their landmark potential and their usability parameters were questioned. In the evaluation, public awareness of environment was also examined. The questionnaire forms used in the evaluation of the parameters were evaluated by using the percentage analysis method and the survey was conducted in May 2018. The questionnaire were made to a total of 70 users in the using study areas most. Some of these users are landscape architecture deparment students who studied urban furnitures lesson previously. The questionnaire were done by asking people face to face.

\section{Findings}

The findings of the study include the investigation of the sustainability of (i) urban furnitures in Rize, and (ii) the potential to be a landmark.

While evaluating the contributions of the objects that can be counted as landmarks such as statues, fountains, urban equipment in the city center of Rize to the identity of the city, the opinions of the participants in terms of material, aesthetics, suitability, form, size and quality were discussed. Considering the socio-demographic structure of the users, $51.4 \%$ of the respondents were women, $48.6 \%$ of them were men, $18.6 \%$ of the participants were $18-25$ years old, $15.7 \%$ of them were $26-30$ years old, $\% 21.4$ of them was $31-35$ years, $12.8 \%$ of them were $36-40$ years old, $21.4 \%$ were $41-50$ years old and $4.3 \%$ were $51-60$ years old. $51.42 \%$ of the participants were married and $48.58 \%$ were single. In addition, $14.3 \%$ of the users have high school or secondary education while $58.6 \%$ have a university degree and $22.9 \%$ have a master's or doctoral degree.

\section{Investigation of Sustainability of Urban Furnitures}

In the questions directed to the users in the first part of the questionnaire, different features (quality, function, dimension, material, extent of usage) of four objects in the categories 1, 2 and 4 and six objects in the category 3 were investigated (Annex 1).

According to the answers of questions 'Do you like these objects?', the most popular among the sculptures is 'The Teapot in Front of the Municipality', while the' Anchovy in Front of the Municipality 'is the last in this area with $38 \%$ liking. Among the fountains, with a rate of $47 \%$, the fountain in front of Tevfik Ileri Industrial Vocational School was the most liked, while the last place was the fountain in Kuyumcular Bazaar with a rate of $33 \%$. In the third category, the Atatürk Statue in front of the Governor's Building' was the first in the region with a rate of $87 \%$. The coastal park Ipsiz Recep Reis Statue was the last with $34 \%$. In the 4 th category, where the equipment elements with different characteristics in Rize City Center are in question, while the lighting element in Deniz Caddesi is in the 1 st place with $80 \%$ admiration rate, Memişağa Park equipment is in the last row.

\section{Investigation of Potential to be a Landmark}

In the questions directed to the users in the second part of the questionnaire, the objects in each category were 
asked to be compared with each other and users were expected to make a sequence among these objects. According to the answers, the preference status of the users is listed and the answers are discussed in the table below. Accordingly, for the first category and first question, $27 \%$ of the users ranked the Sculpture in front of the Municipality Building 1st in the list.

Table 1. Questionnaire part 2 results, examination of the potential to be landmark

\begin{tabular}{|c|c|c|c|c|}
\hline & Statue group & Fountain group & Landmark group & Equipment group \\
\hline 1 & S-2 (\% 27.1) & F-1 (\% 20) & St-1 (\% 31.4) & Eq-1 (\% 21.4) \\
\hline 2 & S-2 (\% 48.6) & F-1 (\% 20) & St-1 (\% 34.2) & Eq-1 (\% 21.4) \\
\hline 3 & S-2 (\% 46) & F-1 (\% 17.1) & St-1 (\% 20) & Eq-1 (\% 28.5) \\
\hline 4 & S-2 (\% 32.8) & F-1 (\% 14.2) & St-1 (\% 44.25) & Eq-1 (\% 28.5) \\
\hline 5 & S-2 (\% 31.4) & F-1 (\% 17.1) & St-1 (\% 38.5) & Eq-1 (\% 22.85) \\
\hline 6 & S-2 (\% 25.7) & F-1 (\% 15.7) & St-1 (\% 35.7) & Eq-1 (\% 18.5) \\
\hline 7 & S-2 (\% 25.7) & F-3 (\% 15.7) & St-1 (\% 31.4) & Eq-1 (\% 20) \\
\hline 8 & S-2 (\% 30) & F-1 (\% 20) & St-1 (\% 27.1) & Eq-1 (\% 20) \\
\hline 9 & S-2 (\% 15.7) & F-1 (\% 17.1) & St-1 (\% 22.8) & Eq-1 (\% 18.5) \\
\hline 10 & S-1 (\% 18.5) & F-1 (\% 15.7) & St-1 (\% 28.5) & Eq-1 (\% 22.85) \\
\hline
\end{tabular}

\section{RESULTS AND DISCUSSION}

Since ancient times, people have used elements such as statues, monuments, etc. In cities and urban areas. Today, in almost every city, such objects are used both because of their aesthetic and cultural or historical meanings. In addition, functional city equipment (lighting, living unit, etc.) are designed in the style of urban furnitures and adapted to the cities. But in many of our cities, these objects used are criticized for their incompatibility with the place where they are used. Similarly, many of the urban furnitures, statues and equipments in the city center of Rize are not appreciated by the inhabitants of the city.

When the results of the evaluation are taken into consideration, 1 of the 4 categories that were questioned, that is, the statue in front of the Municipality, which is the most admired in the sculptures, showed that it is effective in the habits of the people with its size, authenticity, location. For example, this statue was used as a meeting point by $63 \%$ of users. As a matter of fact, Güremen (2011) stated in his study that the visual and physical relationship that the users establish with the city is through urban equipment elements and that these elements define, determine and customize the environment in which they are located. The least favorable anchovy statue is in the lowest rank because there are different objects around it, it is not effective in reflecting the urban identity, it does not stand out in the place where it is located, and it is found unexceptional due to its color and material. The reason for this situation, as in the work of Güremen (2011), urban equipment elements, which have been handled in a certain order and become an element of the city by integrating with the environment they are in, contribute to the formation of a city's identity with the language union they establish with each other.

In the second category, the fountains used at certain points in the center of the city were questioned. The fountain in front of 'Tevfik Ileri I. V. S.' was the most popular fountain with $47 \%$. Also, all fountains were regarded as insignificant by the participants. According to the obtained results, the reason for this is the lack of maintenance of the fountains, incompatibility with the location, material preference, and their not reflecting the local and cultural character. This result; As Appleyard (1969), Beattie (1990) and Moon et al. (2010) stated in their work, the sense of belonging in the city; It is compatible with the expressions that the city equipments are related with the value reflecting the regional identity and recognition by everyone. Likewise, Bulut and Atabeyoğlu (2007) stated that urban furniture are equipment elements that vary depending on the cultural characteristics of the country and cities. 
In the 3rd category, when the objects and spaces that can meet the landmark quality in Rize city were questioned, Atatürk Statue in front of Governor's Building ranked first with $87 \%$ appreciation rate. This result shows that the places and objects that can have the landmark feature should have the public space character, scale, visibility, take place in personal memories, and be effective in habits. Pekin and Timur (2008) said about urban furniture in their work: While they should comply with certain standards in terms of ergonomics and various physical features, their designs should also be considered functional and aesthetic (line, size, shape, color, texture, etc.) and should be as unique as possible. Çınar and Çetindağ (2009) stated in their studies that the space will gain perceptibility and usability continuity. In addition, Ipsiz Recep Reis Statue in the Coastal Park was not regarded as a landmark with a rate of $34 \%$.

In the 4 th category, it is seen that the urban facilities are perceived by the users as similar functions and the functionalities of the preferred objects in urban spaces are in the forefront. It has been determined that the disused seating unit does not conform to the space in color and form. This situation was in conformity with the criteria that could make a difference in the urban furniture design stated in the Aksu study and affect the level of liking of the users; these criteria are as follows; color harmony, size / ratio balance, functional suitability, material harmony, well-maintained / clean, modern, new, historical, reference to history, being different, impressive, interesting, showy, original / unique, good location, being harmony with the environment, being contrast to the environment, being semantic and monumental, symbolic, creating visual richness.

The statues, fountains, landmark and urban equipment which were questioned to the users were evaluated in annex 1 . According to the results of the evaluation, no objects from fountains and equipments come to mind when it comes to Rize. According to the answers given to this question, from the objects bearing the quality of landmark, Atatürk Statue in front of the Governor's Building stands at a rate of $70 \%$, and when the statues are taken into consideration, the rate of $48.6 \%$ is 'the first object that comes to mind when it is called Rize, with a ratio of $46 \%$. and 'Meeting point' with $30 \%$. The Statue of Atatürk in front of the Governor's Building is the objects standing out as a landmark in Rize as it is the most preferred object with a rate of $31.4 \%$, it is found more effective in appearence with a rate of $44.2 \%$, compatible with the place and environment where it is located with a rate of $38,5 \%$, better according to the feature of the place with a rate of $35.7 \%$, it is regarded to have the characteristic of a landmark with a rate of $31.4 \%$ and to be a place where most photos are taken with a rate of $22.8 \%$.

The urban furnitures and sculptures used in the city center of Rize did not come up with a urban furniture that came to the fore with its unique character. As a result of the study, it is seen that the objects that are in the minds of the people have a significant effect on the users, while it is seen that the objects in the visual memory are always perceived in the foreground even if the positions of the objects are changed.

\section{REFERENCES}

Aksu V (1998) Kent Mobilyalarının Yer Aldıkları Mekânlara Etkileri Üzerine-Trabzon Kenti Örneği-Bir Araştırma. Karadeniz Teknik Üniversitesi Fen Bilimleri Enstitüsü Yüksek Lisans Tezi, Trabzon, $118 \mathrm{~s}$

Appleyard D (1969) Why Buildings Are Known: A Predictive Tool for Architects and Planners. Environment and Behavior, 1:2, p.131. Berkeley

Başal M, Y Memlük, O Yılmaz, E. Kurum (1997) Peyzaj Konstrüksiyonu, Ank. Ünv. Zir. Fak. Yayınları: 1484, Ders Kitabı: 445, Ankara, $186 \mathrm{s.}$

Beattie N J W (1990) Imagebility and Cultural Identity, Culture, Space, History, 5: 116

Bulut Y, Atabeyoğlu Ö (2007) Fountains as Urban: Furniture in Historical Urban Structure and Usage Culture: Erzurum City Case. Building and Environment Volume 42, İssue 6, Pages 2432-2438

Can H, Karakaş S (2005) Bilişsel Süreçlerde Alzheimer Tipi Demansa Bağlı Değişiklikler. Klinik Psikiyatri, 37-47

Çınar S, Çetindağ K (2009) Görsel Algılamada Işık ve Renk Faktörü: Sultanahmet Meydanı ve Çevresi Örneği. İstanbul Üniversitesi Orman Fakültesi Dergisi, Seri A, Cilt 59, Sayı 2, 103-120

Diker M, Çolpan Erkan N, (2017) Kent Kimliğinde ibadet Yapıları: Antakya Örneği. Planlama, 2017;27(2), 180-192

Düzenli T, Mumcu S, Eren E. T. (2018) Peyzaj Mimarlığında Heykel Kullanımı: Trabzon Kenti Örneği/Monument Usage in Landscape Architecture: Example of Trabzon City. Journal of History Culture and Art Research, 7(1), 553-564.

Erdoğan E (2006) Çevre ve Kent Estetiği. ZKÜ Bartın Orman Fakültesi Dergisi, Cilt 8, Sayı: 9, 68-77.

Güney A, Erdem Ü, Zafer B, Hepcan, Ş, (1996). Peyzaj Konstrüksiyonu, Ege Üniversitesi Ziraat Fakültesi Yayınları No:514, İzmir, 147s. 
Güremen L, (2011) Kent kimliği ve estetiği yönüyle kentsel donatı elemanlarının amasya kent özelinde araştırılması. e-Journal of New World Sciences Academy Social Sciences, 3C0073, 6, (2), 254-291.

Lynch K (1973) Kent İmgesi. Türkiye İş Bankası Kültür Yayınları, istanbul: 4-62, 87.

Lynch K (1981) A Theory of Good CITY Form, Massachusetts Institute Press, London, $515 p$

Madran E (2001) Kent Belleğinin Oluşumunda Mimarlık Yapıtları. Mimarlık Dergisi, (298): 47-49

Moon K S, Lee H S, Min K M, Lee S J, Kim H J, Kim J J (2010) An Analysis of Landmark Impact Factors on High -Rise Residential Buildings
Value Assessment. International Journal of Strategic Property Management 14, 105-120,

Öksüz A, (2004) Kentsel Alanların Planlanması ve Tasarımı. Ilber Matbaacilık, Trabzon.

Pekin U, Timur B (2008) Kentsel Dış Mekânlar ve Donatı ElemanlarıEskişehir Kenti Örneği. 21. Uluslararası Yapı ve Yaşam Kongresi Bildiriler Kitabı, Bursa, 80-85.

Tekeli i (1991) Kent Planlaması Konuşmaları. TBMM Mimarlar Odası

Tranck R (1986) Finding Lost Space. Von Nostrand Reinhold, New York

Ujang N (2009) Place Attachment and Continuity of Urban Place Identity. Procedia - Social and Behavioral Sciences, 49, 156- 167. 
Annex 1. Survey part 1, investigation of sustainability of urban furnitures

$$
\text { Statues Fountains }
$$

Questions

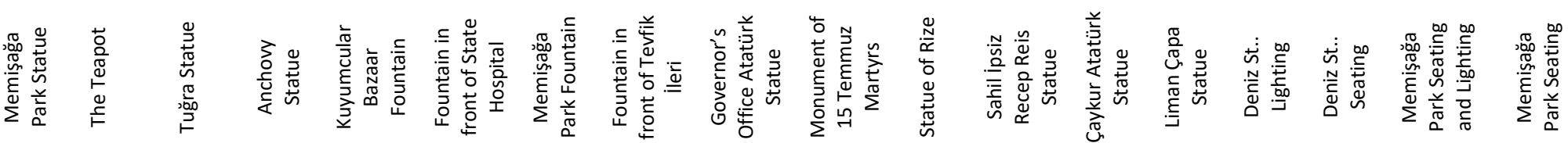

\begin{tabular}{|c|c|c|c|c|c|c|c|c|c|c|c|c|c|c|c|c|c|c|c|}
\hline \multirow{2}{*}{$\begin{array}{l}\text { 1) Do you like these } \\
\text { objects? }\end{array}$} & Yes & 44 & 49 & 45 & 21 & 19 & 27 & 31 & 33 & 61 & 47 & 45 & 41 & 56 & 51 & 56 & 49 & 47 & 36 \\
\hline & No & 22 & 20 & 23 & 44 & 47 & 39 & 36 & 36 & 6 & 19 & 21 & 24 & 8 & 14 & 8 & 19 & 20 & 32 \\
\hline \multirow{2}{*}{$\begin{array}{l}\text { 2) What comes to your } \\
\text { mind when you think } \\
\text { of Rize? }\end{array}$} & Yes & 14 & 51 & 14 & 19 & 16 & 13 & 10 & 12 & 45 & 21 & 42 & 28 & 34 & 26 & 25 & 21 & 23 & 23 \\
\hline & No & 38 & 15 & 42 & 37 & 51 & 51 & 53 & 52 & 19 & 42 & 24 & 35 & 30 & 37 & 41 & 45 & 43 & 43 \\
\hline \multirow{2}{*}{$\begin{array}{l}\text { 3) Does it reflect a } \\
\text { characteristic of the } \\
\text { city of Rize? }\end{array}$} & Yes & 28 & 61 & 12 & 44 & 14 & 13 & 12 & 16 & 36 & 28 & 45 & 38 & 32 & 35 & 26 & 16 & 21 & 19 \\
\hline & No & 31 & 9 & 45 & 20 & 54 & 52 & 54 & 48 & 28 & 35 & 21 & 26 & 32 & 29 & 38 & 50 & 45 & 48 \\
\hline \multirow{2}{*}{$\begin{array}{l}\text { 4) Are the dimensions } \\
\text { of the fountains used } \\
\text { suitable for visibility? }\end{array}$} & Yes & 44 & 54 & 44 & 28 & 17 & 35 & 36 & 36 & 59 & 39 & 43 & 36 & 54 & 47 & 40 & 42 & 45 & 43 \\
\hline & No & 23 & 16 & 23 & 39 & 50 & 31 & 30 & 28 & 7 & 27 & 25 & 30 & 12 & 20 & 27 & 25 & 22 & 25 \\
\hline \multirow{2}{*}{$\begin{array}{l}\text { 5) Is it compatible with } \\
\text { its location and } \\
\text { surroundings? }\end{array}$} & Yes & 43 & 55 & 31 & 24 & 16 & 24 & 23 & 26 & 55 & 33 & 47 & 33 & 50 & 51 & 40 & 42 & 45 & 43 \\
\hline & No & 21 & 14 & 31 & 42 & 49 & 40 & 41 & 38 & 9 & 29 & 17 & 29 & 14 & 11 & 27 & 25 & 22 & 25 \\
\hline \multirow{2}{*}{$\begin{array}{l}\text { 6) Is it chosen } \\
\text { according to the } \\
\text { characteristics of the } \\
\text { location? }\end{array}$} & Yes & 34 & 39 & 26 & 24 & 15 & 18 & 20 & 19 & 52 & 31 & 37 & 31 & 43 & 49 & 32 & 28 & 31 & 29 \\
\hline & No & 33 & 29 & 39 & 41 & 49 & 43 & 42 & 43 & 12 & 31 & 27 & 31 & 21 & 13 & 34 & 37 & 34 & 36 \\
\hline \multirow{2}{*}{$\begin{array}{l}\text { 7) Is this object a } \\
\text { landmark? }\end{array}$} & Yes & 23 & 44 & 27 & 26 & 11 & 15 & 14 & 18 & 41 & 24 & 38 & 29 & 33 & 35 & 25 & 15 & 21 & 16 \\
\hline & No & 37 & 19 & 33 & 35 & 51 & 46 & 48 & 43 & 19 & 37 & 25 & 32 & 28 & 27 & 39 & 45 & 42 & 48 \\
\hline \multirow{2}{*}{$\begin{array}{l}\text { 8) Have you ever used } \\
\text { it as a meeting point? }\end{array}$} & Yes & 23 & 44 & 17 & 13 & 6 & 8 & 10 & 6 & 35 & 11 & 23 & 15 & 18 & 17 & 24 & 18 & 16 & 19 \\
\hline & No & 40 & 24 & 47 & 51 & 58 & 55 & 54 & 56 & 28 & 49 & 41 & 45 & 44 & 43 & 40 & 47 & 48 & 46 \\
\hline \multirow{2}{*}{$\begin{array}{l}\text { 9) Have you ever used } \\
\text { it to take a photo? }\end{array}$} & Yes & 13 & 20 & 11 & 8 & 5 & 6 & 5 & 6 & 26 & 16 & 24 & 19 & 16 & 17 & 13 & 11 & 11 & 13 \\
\hline & No & 52 & 45 & 53 & 57 & 59 & 58 & 57 & 57 & 38 & 46 & 40 & 43 & 45 & 44 & 52 & 54 & 53 & 52 \\
\hline \multirow{2}{*}{$\begin{array}{l}\text { 10) Are the different } \\
\text { materials being used } \\
\text { with a fountain } \\
\text { interesting for you? }\end{array}$} & Yes & 27 & 24 & 21 & 20 & 25 & 30 & 29 & 28 & 37 & 30 & 31 & 29 & 30 & 30 & 32 & 31 & 33 & 26 \\
\hline & No & 38 & 42 & 45 & 45 & 38 & 33 & 33 & 34 & 28 & 31 & 32 & 34 & 32 & 33 & 34 & 34 & 32 & 39 \\
\hline
\end{tabular}

